\title{
Sten som betydelsebärare i den förhistoriska föreställningsvärlden
}

\author{
MARIANNE LÖNN
}

Lönn, M. 2020. Stones as bearers of meaning in prehistoric worldviews. AmS-Varia 61, 77-86, Stavanger, ISSN 0332-6306, ISBN 978-82-7760-187-8

This article discusses the meaning of stones and the practice of gathering stones, in graves, clearance cairns and stone-covered hillocks. The emphases are on stone-covered hillocks and their long-term usage (up to 1500 years), analyzed using the concept of longue durée. In this paper I propose that the stones in themselves have a cultic meaning as well as the actions, i.e. the remodeling of hillocks and the placing of clearance cairns among graves. In this, I see a connection between stone-covered hillocks, graves and clearance cairns. The underlying concept is a stable, but slowly changing, prehistoric religious tradition that lasted from the Bronze Age to the Migration Period and possibly also through the Late Iron Age. A basic change in this does not take place until the coming of Christianity in the Medieval Period. The reason that Medieval and later clearance cairns were placed together with graves is probably due to their similar appearance.

Marianne Lönn, Sävelycke 515, S-44492 JÖRLANDA, SWEDEN. E-mail: marianne.lonn@gmail.com

Keywords: stone packings, stone-settings, stone-covered hillocks, religious philosophy, cult, continuity, longue durée.

\section{Inledning}

I förhistorien är sten såväl ett bygg- och verktygsmaterial som en bärare av kulturella föreställningar. Det kan givetvis också vara något man tar bort från åkern eller betesmarken. Sten är något önskvärt, något icke önskvärt, praktiskt, kultiskt eller betydelselöst. Kort sagt, sten är något komplicerat, något med många sidor och många tolkningsmöjligheter, som dessutom skiftar över tid. Sten är dock så vanligt och självklart vid arkeologiska undersökningar, att den kan bli är osynlig i tolkningarna. I detta vill jag ta fram betydelsen av sten.

Det seminarium som speglas i den här artikelsamlingen, handlade om svårigheten i att skilja mellan gravar och odlingsrösen vid planering av arkeologiska undersökningar. I min artikel vill jag visa, att det finns fler fornlämningstyper som kan förväxlas med ovannämnda lämningar. Den jag då särskilt tänker på är en ganska nyfunnen fornlämningstyp, som kan kallas stenklädda berg. Jag vill påstå, att det dessa fornlämningar har gemensamt, nämligen sten, inte bara är ett byggnadsmaterial utan i högsta grad en betydelsebärare i föreställningsvärlden. Jag menar och hoppas också kunna visa, att sten har haft kultisk betydelse under en mycket lång tid och att det kultiska betydelseinnehållet förändrats över tid.

Jag vill också göra troligt, att det kan finnas en koppling mellan de stenklädda bergen och gravarna och att den kopplingen består av just sten, stenpackningar och omflyttande av sten.

Först en definitionsfråga. För mig, en svensk arkeolog som huvudsakligen har arbetat i Bohuslän, är ett 'röse' en specifik bronsåldersgrav oftast belägen högst uppe på bergstoppar. Således kallar jag inte ett 'röjningsröse' för enbart 'röse'. De gravar, som kan förväxlas med röjningsrösen, är i min terminologi stensättningar eller oregelbundna stensättningar.

\section{Stensättningar, röjningsrösen och stenklädda berg}

Stensättningar och röjningsrösen är två typer av stenhögar, som representerar olika sidor av en förhistorisk verklighet. Gravtypen stensättningar med sin koppling till liv och död har samband med föreställningsvärlden, medan röjningsrösen i första hand hör 
Fig. I. Skee 1597. Det arkeologiska uppdraget för förundersökningen av Skee 1597 var att bestämma om stenhögen var ett röjningsröse, en grav eller ingenting alls. Det visade sig vara en romartida grav med spannformat kärl, som använts som röjningsröse under sen tid. Foto: Marianne Lönn. Fig. I. Skee 1597. The archaeological task for the preliminary investigation at Skee 1597 was to determine whether the stone pile was a clearance cairn, a grave or nothing at all. It turned out to be a Roman Iron Age grave with bucket-shaped pottery, which had been used as a clearance cairn during Modern Times. Photo: Marianne Lönn.

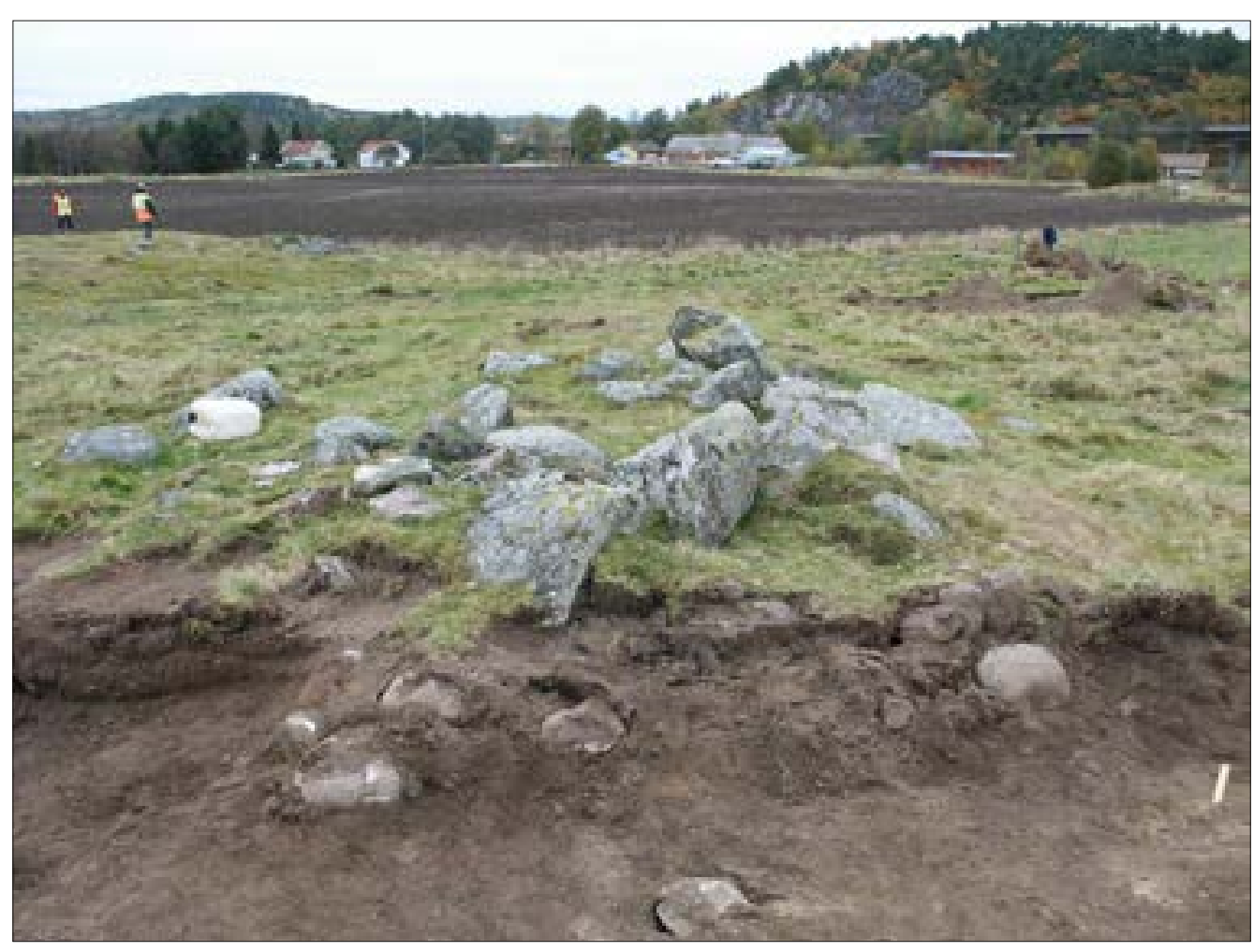

ihop med mödan att skapa odlingsbara ytor. Dock kan det naturligtvis smyga sig in kultiska handlingar även i stenröjning av en åker, speciellt i en tid då skillnaden mellan religiöst och profant sannolikt inte var så uppdelad som idag.

Skillnaden i utseende mellan fornlämningskategorierna stensättningar och röjningsrösen kan vara liten eller ingen (Fig. 1). De kan vara så lika att det är svårt att veta vad som är vad, vilket omvittnas av de flesta arkeologer i fält. Även i förhistorisk tid verkar det ha varit svårt att skilja de båda kategorierna åt. Man ser då och då gravhögar som har fått en fortsatt användning som röjningsrösen och tvärtom, även om det senare verkar vara mindre vanligt. (jfr t.ex. Häggström, 2005; Lönn, 2009). Om stensättningar övergår till att bli röjningsrösen har stenen tappat sin betydelse. Vid det omvända har stenen fått betydelse. Det finns också områden med röjningsrösen och stensättningar blandat (jfr t.ex. Häggström, 2005; Ängeby \& Connelid, 2016). Då blandas inte bara fornlämningskategorier utan också betydelsebärande sten och åtminstone initialt icke betydelsebärande sten.

Överraskningar, då röjningsröset visar sig vara något annat, är vanliga och orsakar inte sällan problem med budget, uppfyllelse av undersökningsplan och annat. Problemen och överraskningen kan dock bli ännu större om man överraskas av en helt annan typ av lämning, dvs. de relativt nyligen identifierade stenklädda bergen, stenflaken eller vad de ska kallas (jfr Munkenberg,
2012). Det finns ännu ingen allmänt accepterad terminologi här. Lämningarna består av naturlig sten, som lagts på och runt berg eller bergskanter. De kan också vara naturliga åsar eller andra samlingar av sten där stenen plockats runt på olika sätt. Hos dessa lämningar verkar stenen vara oerhört betydelsebärande.

Vad vi hittills vet om dessa stenkonstruktioner är, att de tidsmässigt huvudsakligen hör hemma från mitten av bronsålder till slutet av äldre järnålder. Hos några finns dock även spår av aktiviteter från senneolitikumäldre bronsålder och yngre järnålder. De har alltså varit i bruk ungefär samtidigt som många stensättningar och röjningsrösen.

\section{Stenklädda berg på Hisingen i Göteborg och på olika ställen i Bohuslän}

1975 skulle en helt vanlig oregelbunden stensättning på en bergknalle undersökas (Tuve 65, Andersson, 1976) (Fig. 2). Emellertid visade det sig att alla skrevor och fördjupningar på berget var stenfyllda och det låg ett tre till fem meter brett brätte av sten runt foten av bergknallen. Totalt mätte anläggningen $60 \times 40 \mathrm{~m}$. Det som från början setts som en grav på toppen av berget var något helt annat och mycket större. Den förmodade graven på knallens topp var ingen grav utan en stensättningsliknande packning. Däremot fanns en grav utanför berget och en osäker sådan en bit ner på berget.

Slagen flinta var den största fyndgruppen och den fanns spridd över hela berget. I övrigt fanns flintredskap, 


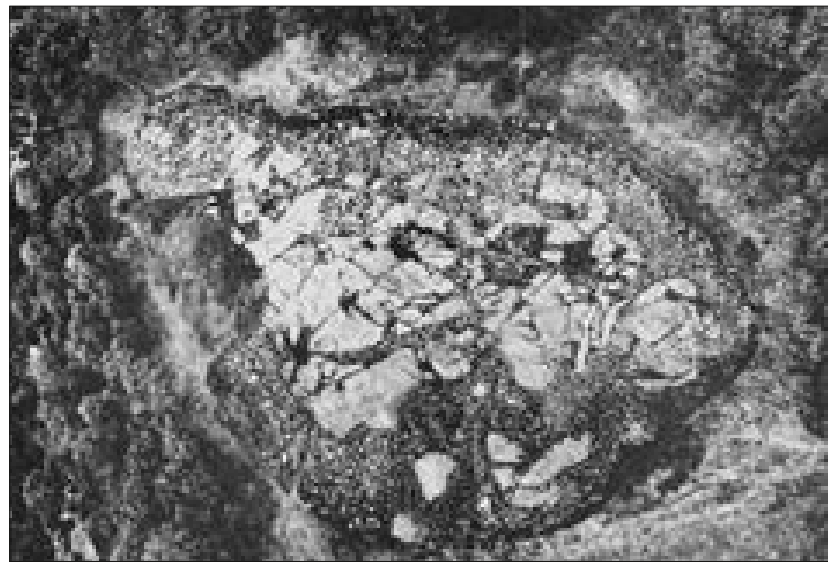

Fig. 2. Översikt över Tuve 65. En icke undersökt tårtbit syns i överkanten. Lodfoto från helikopter. Fotograf ej angiven. Fig. 2. View over Tuve 65. An unexcavated part can be seen in the upper part of the picture. Photo taken from helicopter. The photographer is not specified.

harts, lerkula, bränd lera och keramik. Det sistnämnda dels glest spritt över berget, dels i några koncentrationer. Anläggningen som helhet daterades till bronsålder och förromersk järnålder.

Anläggningen tolkades som ett kultberg trots att den undersöktes under arkeologins mest processuella och tolkningsmässigt profana period. Det fanns inga andra möjligheter. Det stenklädda berget var oförståeligt ur alla praktiska synvinklar och helt unik och det fortsatte att vara ensamt i sitt slag under ca. 20 år. Först på sent 1990-tal dök liknande stenklädda berg och bergskanter upp vid undersökningar i Bohuslän.

Eftersom fornlämningstypen är relativt ny och framför allt dåligt definierad, är det svårt att säkert bestämma vad som hör dit och inte. Även klyftor i berget runt bronsåldersrösen och runt högt liggande stensättningar kan vara stenfyllda. I vissa bronsåldersrösen kan det dessutom finnas ett spritt flintmaterial liknande det $\mathrm{i}$ de stenklädda bergen (Lundby 5:1, föredrag 23/2 2018 av Ulf Ragnesten, Göteborgs Stadsmuseum och Gisela Ängeby, Arkeologerna, Statens Historiska museum. Rapport ej klar.) Likaså finns det ibland högst naturliga stenpackningar runt bergsknallar. Nedanstående exempel är därför ett litet urval av de mest tydliga.

År 1997 undersöktes Svarteborg 116, ett ovalt format, tre meter högt och $25 \times 12 \mathrm{~m}$ stort berg omgärdat av ett brätte i sten med en bredd på mellan 12 och $22 \mathrm{~m}$ (Fig. 3). Under stenen anades en bädd av trästockar. Även sprickor och gropar på berget var fyllda med sten. Hela anläggningen mätte $37 \times 34 \mathrm{~m}$. Under stenpackning fanns hällristningar (skepp och skålgropar) och invid fanns ett hus, stensättningar, härdar, kokgrop och årderspår samt flinta, keramik, bränd lera, harts, kvarts, diabas och brända ben. Platsens nyttjandeperiod

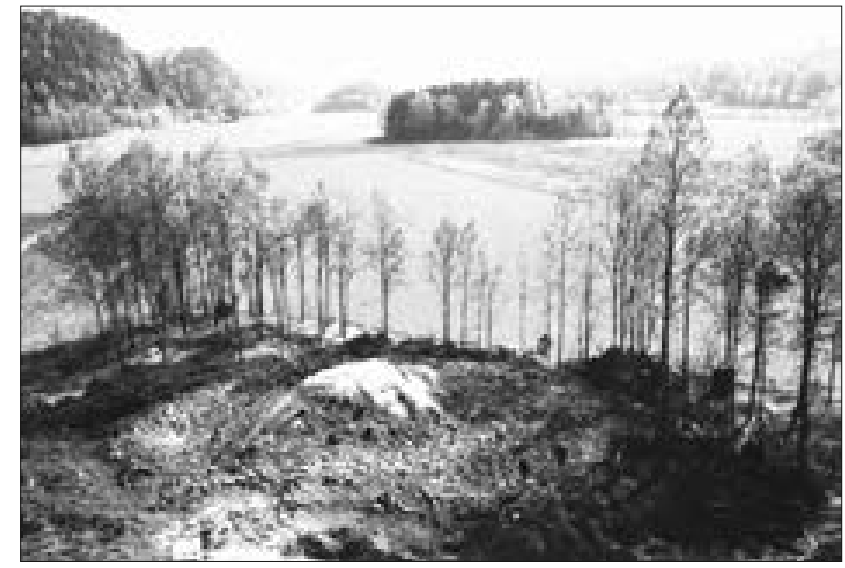

Fig. 3. Svarteborg 116. Fotograf ej angiven.

Fig. 3. Svarteborg /16. The photographer is not specified.

konstaterades vara lång, från äldre bronsålder till medeltid (de yngsta dateringarna kommer dock från granpollen, som skiljer sig mycket från övriga dateringar och därför är svåra att förstå). De flesta dateringarna stammade från förromersk järnålder, men själva stenpackningen på och vid berget tycktes vara skapad så sent som i folkvandringstid/vendeltid (Munkenberg, 2003, 2004).

År 2003 undersöktes en ca. 30 x 40 m stor, lagd stenpackning på toppen av ett berg och med vid utsikt över Saltkällefjorden (Fig. 4). Anläggningen hade brukats från äldre bronsålder till och med äldre järnålder, möjligen ännu längre. Där fanns även tidig- och mellanneolitiska fynd och en ringnål från vikingatid. Anläggningen innehöll gravar, härdar, kokgropar, brända ben, bronsföremål, glaspärlor, bränd lera, keramik, flinta och kvartsit (Foss 239, Lindqvist \& Toreld, 2005).

På en bergskant invid gravfältet Skee 1050, som undersöktes 2007, låg en lagd stenpackning på ca 25 x 15 m (Fig. 5). Denna innehöll fynd som brända ben av människa, flinta, keramik, bränd lera, glas, bergart, harts och kvarts. Stenpackningen daterades huvudsakligen till förromersk och romersk järnålder (Ängeby, 2009).

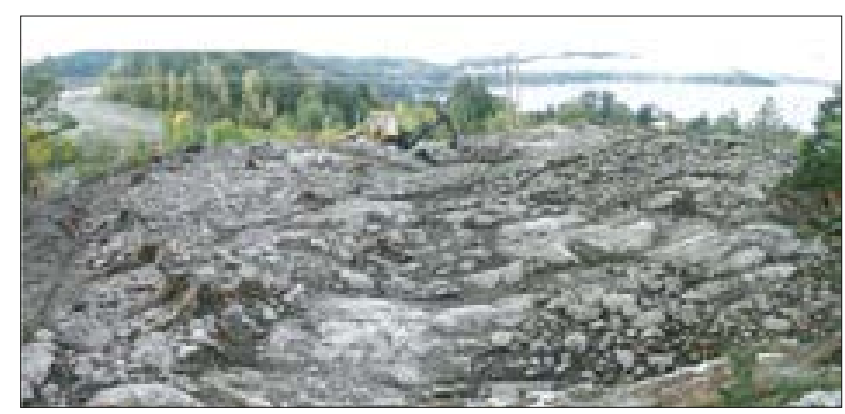

Fig. 4. Foss 239. Fotomontage: Mats Lindqvist.

Fig. 4. Foss 239. Photomontage: Mats Lindqvist. 
Fig. 5. Skee 1050. Foto: Marianne Lönn.

Fig. 5. Skee 1050. Photo:

Marianne Lönn.
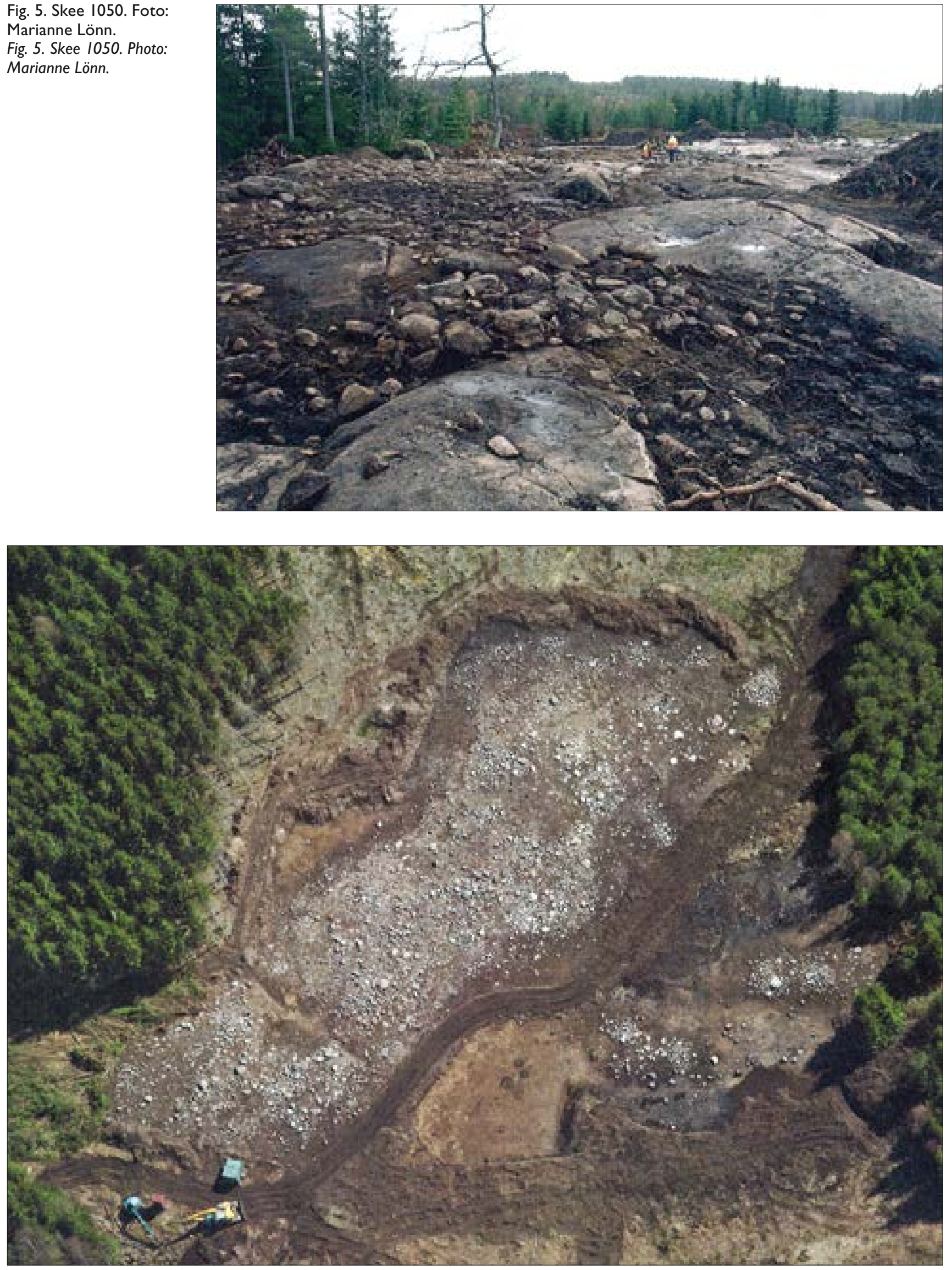

Fig. 6. Tanum 2213. Foto: Markus Andersson.

Fig. 6. Tanum 2213. Photo: Markus Andersson 


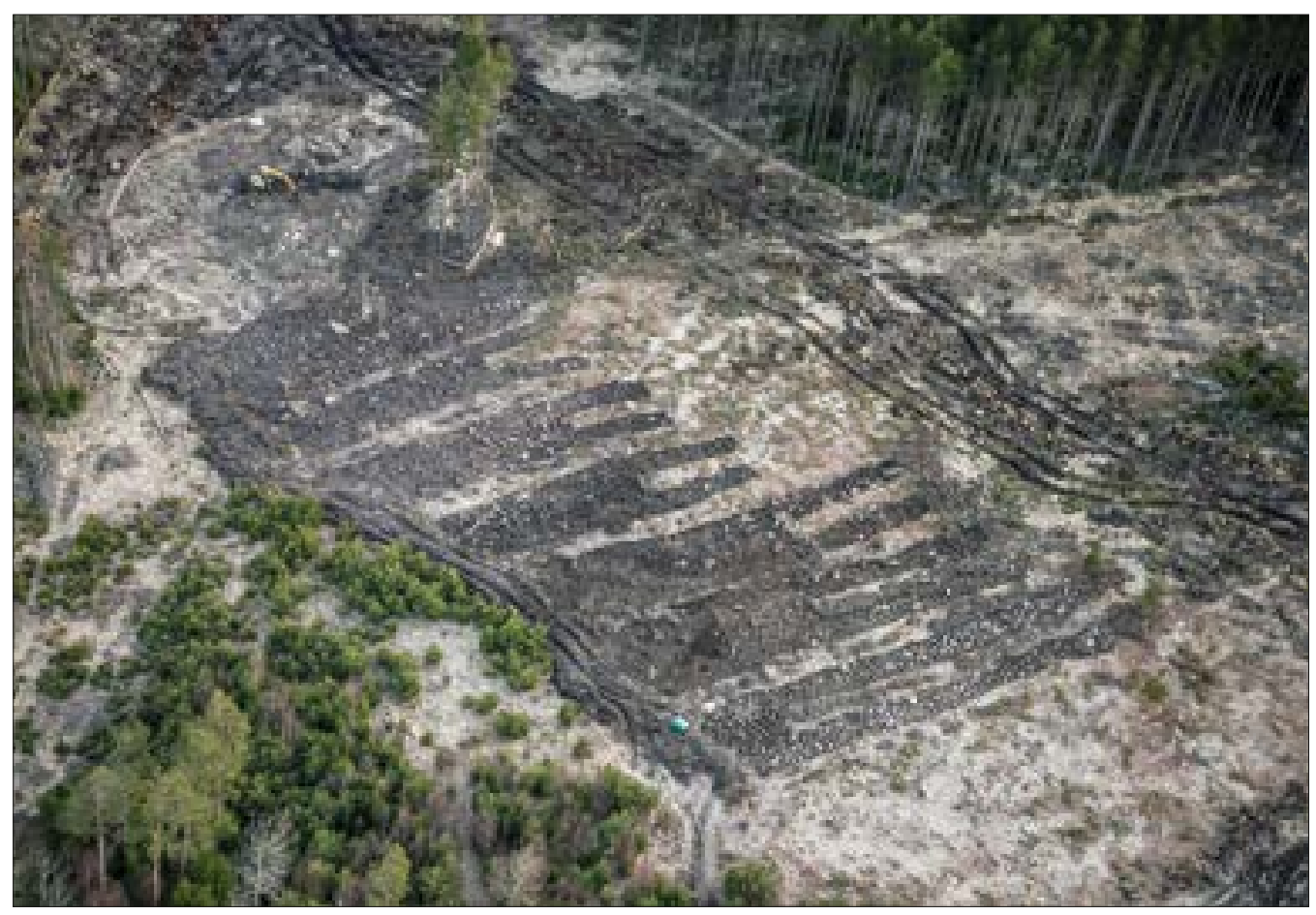

Fig. 7. Tanum I796/2259.

Foto: Per Petersson, perpixel.se.

Fig. 7. Tanum 1796/2259.

Photo: Per Petersson,

perpixel.se
År 2013 undersöktes en 100 x 30 m stenklädd ås där sten plockats runt för att skapa olika formationer (Tanum 2213, Munkenberg \& Claesson, 2014) (Fig. 6). I området fanns också härdar, gropar, kokgropar, stolphål, rännor, hålväg och keramik. Dateringen byggde i första hand på keramiken och gav i huvudsak ett intervall från yngre bronsålder till förromersk järnålder med en tyngdpunkt just $\mathrm{i}$ övergången mellan bronsoch järnålder. Där fanns emellertid också ett mindre antal skärvor från övergången mellan senneolitikum och äldre bronsålder.

Ytterligare en svårbedömd och framför allt svåravgränsad lämning grävdes fram 2013 (Tanum 1796/2259, Östlund \& Swedberg, 2014) (Fig. 7). Även där fanns gravar i form av stensättningar och en omfattande, åtminstone delvis lagd stenpackning, anläggningar i form av härdar, kokgropar, kulturlager och stolphål samt lite flinta och keramik.

Gemensamt för alla är sten, berg och något slags kultiska uttryck samt dateringar till i huvudsak perioden (yngre) bronsålder-äldre järnålder. Dock förekom hos flera av lokalerna även dateringar till senneolitikumäldre bronsålder och hos några senare dateringar. I åtminstone några fall var de äldre dateringarna helt klart rester av aktiviteter, som inte har med stenpackningarna att göra. Liknande lämningar har påträffats även utanför Göteborg och Bohuslän. Den mest kända och möjligen också mest omfattande är Nibble (Tillinge 335 m.fl. (Artursson, Karlenby \& Larsson (Red.), 2011; Karlenby, 2011).
Sin verkliga like fick dock det först påträffade stenklädda berget Tuve 65 först år 2011, alltså 36 år senare. Då påträffades ett till utseendet likt, men än mer innehållsrikt stenklätt berg med brätte. Totalt mätte anläggningen 70 x 30 m (Tuve 46, Lönn, 2014). Även det andra låg på Hisingen bara en kilometer från det första. Eftersom detta är det hittills mest innehållsrika av denna typ av lämningar, och för att jag känner det väl, ska jag gå lite närmare in på det och även jämföra det med Tuve 65.

Efter förundersökningen 2007 av Tuve 46 bedömdes platsen vara av i huvudsak bronsålderskaraktär, men med ytterligare tidsperioder inblandade (Åberg, 2008). I Länsstyrelsens förfrågningsunderlag ansågs platsen innehålla en boplats av i huvudsak bronsålderskaraktär med röjningsrösen, som skulle kunna vara gravar. Där fanns också spridda inslag från flera förhistoriska perioder, framför allt förromersk järnålder (Lönn, 2014, 2015). Platsen såg då ut som en mycket ojämn gräs-, ris- och buskklädd yta i en skogsdunge, och den var både svårundersökt och svårbedömd. När träden var nertagna och ytan röjd, tog det dock inte mer än ett par dagars avbaning vid slutundersökningen för att inse, att detta var något helt annat. Det blev alltså en större variant av Tuve 65 . På berget fanns tre säkra stensättningar och tre osäkra gravar, två skärstenshögar, ett kulthus, en stor röseliknande stenpackning på toppen av berget, cirka fem småstenspackningar, tre keramikkoncentrationer med brända växtdelar/möjliga platser för brandoffer, runt 20 flintslagningsplatser/depåer 

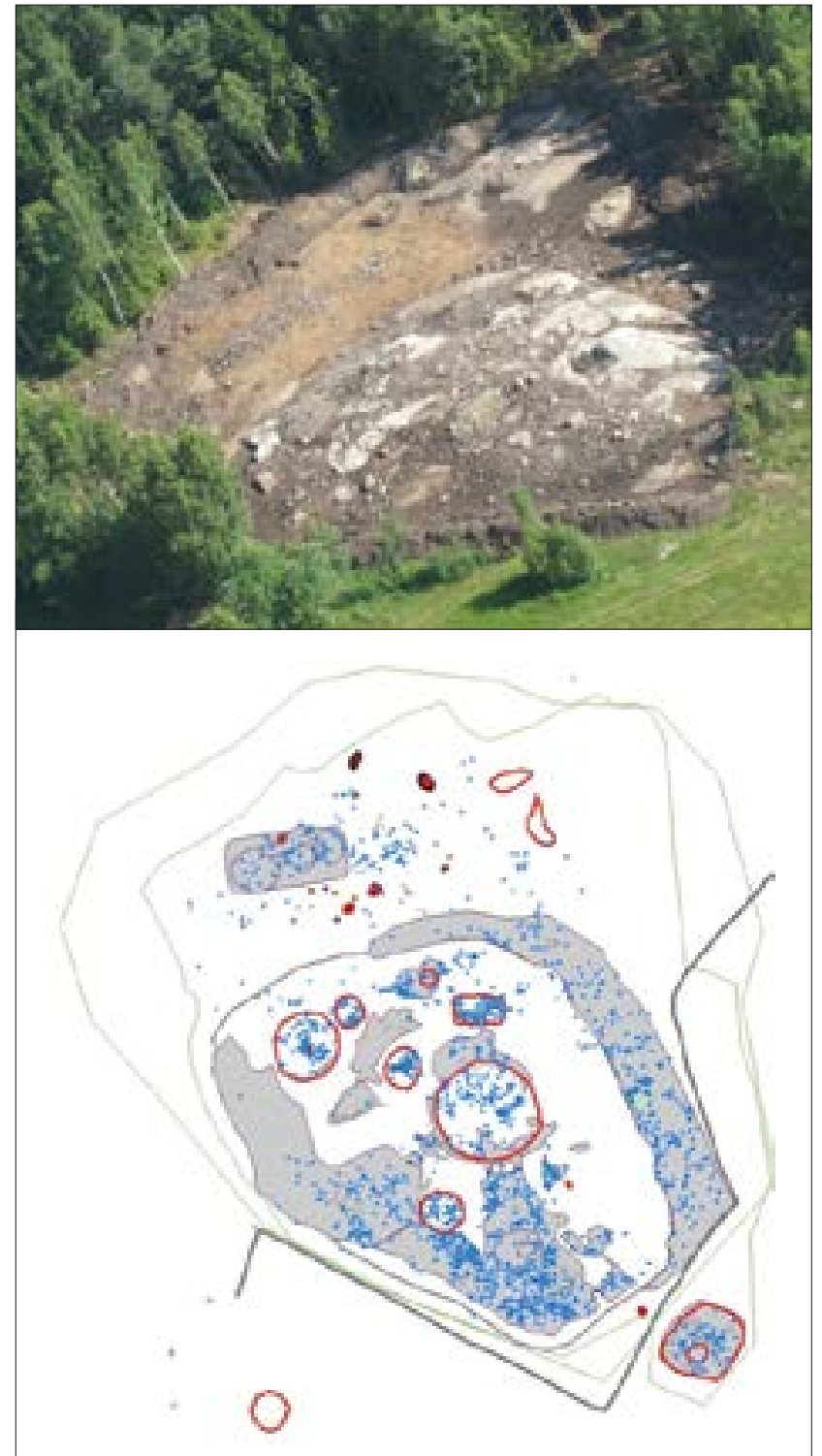

Fig. 8. Översikt över Tuve 46, A) flygfoto, B) skiss med anläggningar. Foto: Marianne Lönn.

Fig. 8. View over Tuve 46, A) aerial photo, B) sketch with structures. Photo and sketch: Marianne Lönn.

med produktionsavfall samt stolphål, gropar, kokgropar, härdar, skärvstensflak, slagen flinta, flintredskap, keramik, bränd lera, lerkulor, brända ben och kvarts. De flesta fynden låg, liksom på den andra Tuvelokalen, i stenpackningen. Inte bara sten var flyttade till berget, utan även stora block (Fig. 8).

Bergknallen hade brukats i senmesolitikum (enstaka fynd), i neolitikum (flintslagningsplatser, flintredskap, keramik, ett C14-resultat från en flintslagningsplats), från mitten av bronsålder till förromersk järnålder (keramik, 15 C14-resultat från gravar, skärvstenhögar, kulthus, eventuella brandofferplatser, härdar, kokgrop och block med brätte) och från romersk järnålder till folkvandringstid (keramik). Eldningen på platsen verkar huvudsakligen ha skett under andra halvan av bronsåldern och lite in i förromersk järnålder. Kontinuiteten i detta var lite oklar, men sannolikt fanns det två skilda aktivitetsperioder. En pågick under neolitikum och en från mitten av bronsålder till folkvandringstid. Tolkningen av de båda blev att berget använts som plats för tillverkning av flintredskap under neolitikum och som kultplats/samlingsplats från bronsålder till folkvandringstid. Större delen av anläggningen skapades under den andra halvan av bronsålder och i början av förromersk järnålder. Därefter brukades platsen genom återkomster under förromersk järnålder, romersk järnålder och folkvandringstid, alltså under runt 1000 år. Under denna senare period förändrades dock bruket och ritualerna från att bland annat innehålla eldning och begravningar till något som enbart efterlämnade fynd, framför allt keramik.

Både Tuve 65 och Tuve 46 var ursprungligen ganska låga bergsknallar, vars alla fördjupningar och skrevor var fyllda med sten, och runt bergen fanns ett flera meter brett stenbrätte. Det såg ut som om man velat bygga om berget och göra det rundare och jämnare i formen. Anläggningar av olika slag var närmast inklädda i sten. Dessutom fanns en stensättningsliknande anläggning på toppen av Tuve 65 och en välplanerad röseliknande stenpackning på högsta delen av berget på Tuve 46. I den senare fanns, förutom själva stenpackningen cirklar av större block med vartannat block i rödaktig färg och vartannat i blåaktig. Tuve 65 tolkades som en kultplats och jag, som var projektledare på Tuve 46, såg även detta berg som en sådan, kanske något slags harg (se definition nedan), där mittpackningen var centrum. Jag tänkte mig att människors syfte med båda platserna var att skapa samlingsplatser för olika typer av kultiska aktiviteter.

Platsernas läge i landskapet var på intet sätt spektakulärt. Det var fråga om ganska små och låga bergknallar, som låg $\mathrm{i}$ ett lätt kuperat landskap en bit in från kusten och likaså en bit från farbara åar. Ändå är platserna inte svårtillgängliga. Man kan relativt lätt ta sig dit även om det inte kan ske per båt ända fram. Möjligen kan det senare vara ett tecken på att dessa båda berg fungerat i ett lokalsamhälle och att de inte varit tänkta för långväga resande längs vattnen.

Det är svårt att förstå dessa stenklädda berg och bergskanter och omflyttandet av sten i naturliga stensamlingar på annat sätt än kultiskt. Sten och berg har haft en plats i föreställningsvärlden och det finns flera exempel på kopplingar mellan sten/berg och kult allt från konstigt formade stenar till heliga höga berg. I den norröna föreställningsvärlden finns bland annat begreppet 'harg'. Ursprungligen hade ordet på 
fornvästnordiska troligen betydelsen 'stenrik mark', vilket utvecklades till 'stenhög, helgedom' (Vikstrand, 2001, s. 201ff).

Begreppet 'axis mundi' betyder 'världen mitt' och var en kosmisk centrumsymbol, som indikerade en koppling mellan himmel och jord (Kaliff, 1997; Gerdin, 1999; Artelius, 2008; Karlenby, 2011). Denna kosmiska symbol kunde manifesteras på många sätt, bland annat genom sten/stenhögar på berg. I min tolkning av Tuve 46 såg jag den röseliknande stenpackningen mitt på berget som ett möjligt 'axis mundi'.

Det faktum att många gravar byggdes av eller innehöll sten bör också tillskrivas betydelse, liksom att man kan se att sten på gravar och på andra ställen lagts i vissa formationer. Olika färger på sten utnyttjades också för att skapa intryck eller former (Kraft, 2013).

\section{Långtidsanalys}

De stenklädda bergen har en mycket lång bruksperiod inom vilken bruket förändras. De representerar en företeelse, som passar att analyseras utifrån tankarna bakom begreppet 'longue durée'. Longue durée (Braudel 1980; Bintliff 1991) poängterar just förändring över lång tid. Inriktningen utvecklades som en motpol till 'the history of events' inom de sociala vetenskaperna (l'histoire événementielle, Braudel, 1980, s. 27), alltså att arbeta med förändring utifrån enskilda, snabba händelser. Enligt longue durée tänker man sig istället att varaktiga krafter såsom stabila sociala strukturer eller ideologier påverkar samhället och ger långsamma och ihållande förändringar. Dessa kan ske på flera plan och påverka olika sidor av samhället så att vissa företeelser lever vidare, medan andra delar av samhället förändras. Emellertid finns inom denna ständiga, långsamma förändring även utrymme för snabba omdaningar så, att flera förändringsskeenden kan försiggå samtidigt.

Longue durée berör mycket långa händelseförlopp och mycket generella utvecklingar i fråga om civilisationer, folk, stabila teknologier och liknande. Ett mellansteg mellan history of events och longe durée är vad som kallas 'structural history'. Det senare avser något kortare men fortfarande relativt långa tidsperioder, flera generationer eller sekler. Det är också viktigt att notera, att förändringar inom både structural history och longue durée är omärkliga, icke iakttagbara för en människa.

I boken The Significance of Monuments beskriver Richard Bradley (1998) bland annat hur monument, som brukas under lång tid, genomgår förändringar. De byggs om och byggs ut på olika sätt. Det är tänkbart, att monument, som ser olika ut, inte är olika typer utan representerar skilda stadier i en fortgående ombyggnadsprocess. Vissa har helt enkelt upphört att användas innan hela processen avslutats och har därför inte hunnit få alla de element som finns hos andra. I materialet ovan finns exempelvis en skillnad mellan Tuve 46 och Tuve 65 i det att Tuve 65 saknar de spår av senare användning av stenpackningen som finns genom keramik daterad till romersk järnålder och senare på Tuve 46. Tuve 65 upphör att användas efter förromersk järnålder. Orsakerna till omdaningarna finns, enligt Bradley (1998), i samhället runt omkring.

Hur ska man då se det stensatta bergets, Tuve 46 , förändringshistoria? De skeenden som har dokumenterats är: Sten och block hämtas och läggs på berget så att detta omformas. Stenpackningen används. Ett centrumröse med cirklar och olikfärgade stenar byggs. Gravar byggs och begravningar hålls. Eldning sker på delar av berget. Skärvstenshögar skapas. Kulthus byggs. Eldoffer utförs. Kokgropar används. Härdar eldas i. Flint- och keramikbitar strös över stenpackningen. Berget överges.

Det är många aktiviteter, men sett genom tidsskalan blir bilden mindre brokig. Allt utom användandet av stenpackning, ströende av flint- och keramikbitar samt övergivande har skett inom en snäv period i yngre bronsålder, kanske till och med under en betydligt kortare tid. Osäkerhetsmarginalerna hos C14 sätter dock stopp för en sådan bestämning. Det som finns kvar av aktiviteter mellan övergången till förromersk järnålder och övergivandet i folkvandringstid, är alltså att man använder stenpackningen genom att strö mest keramik, men antagligen även flintbitar i den. Det är möjligt att stenpackningen också byggs på, men det går inte att säga bestämt eftersom det inte går att datera en sådan aktivitet.

Förutom den neolitiska flintan från slagplatserna på berget fanns även flintbitar, som kan ha slagits under järnåldern. Den mesta keramiken kan dateras till sen bronsålder och förromersk järnålder, alltså direkt efter bygg- och eldningsperioden. Under romersk järnålder och folkvandringstid har man fortsatt strö ut keramik i stenpackningen om än i mindre grad. Det stensatta bergets historia består alltså av ett intensivt byggande, begravande och eldande i yngre bronsålder, och därefter ett allt mer avtagande bruk bestående av besök som avsätter keramik i stenpackningen. Intressant i detta är att stenpackningen/stenen verkar vara det bärande elementet över tid. Det är den som har använts fast på olika sätt.

Att bygga med sten, att omforma berg och att använda stenpackningen genom att sprida flint- och keramikbitar i den är aktiviteter, som upprätthålls under hela det 
stensatta bergets användningstid. Det är alltså osäkert om stenpackningen byggs färdig direkt eller byggs på över tid, men utnyttjandet av den är konstant. Även i de andra monumenten är sten, förflyttandet av sten och utnyttjandet av stenpackning bärande element.

Bakgrunden till stenbyggandet bör ligga i föreställningsvärlden eftersom dessa monument sannolikt har med kulten att göra. Det är dessutom en av de bakomliggande orsaker till stabilitet, som nämns inom longue durée (Braudel, 1980; Bintliff, 1991). Omvänt, en orsak till förändring kan vara omdaningar i samhället (Bradley, 1998) och möjligen har de folkvandringstida omdaningarna påverkat bruket av de stenklädda bergen, men vad som ligger bakom förändringen från de intensiva aktiviteterna till besök, som efterlämnar flinta och keramik, kan jag inte säga.

\section{Återbruk eller kontinuitet?}

I fallet stenklädda berg diskuterar vi brukskontinuitet för en enskild, men ihärdigt använd lämning. Man kan också fundera kring kontinuitet och samband mellan olika lämningar. Det finns många exempel på återbruk både i förhistorien och historien. En del är äkta kontinuitet, andra beror på feltolkningar eller missförstånd.

Våra egna missbedömningar i fråga om stensättningar och röjningsrösen beror på att de är så lika varandra, och samma orsak kan ha varit fallet när bronsålderns och äldre järnålderns människor lade röjningssten på gravar. Men möjligen är det inte fråga om ett missförstånd, utan ett fortsatt bruk av sten och stenpackningar enligt tidens föreställningsvärld (jfr diskussion hos Kraft, 2003).

Den långa kontinuiteten hos de stenklädda bergen visar, att de överlevde förändringar i sättet att bruka dem. Meningsinnehållet förändrades sakta och gradvis, men platsen, berget och stenen behöll ändå en betydelse. Troligen har enskilda människor inte märkt utvecklingen (Braudel, 1980; Bintliff, 1991). En hypotetisk fråga blir då: Kan ett gravfält med stensättningar få en motsvarande förändrad funktion så att man fortsätter att lägga sten där, även om man inte begraver någon? Var det i så fall viktigt att skapa vällagda röjningsrösen? Kan ett gravfält helt enkelt övergå till att bli en plats för sten/röjningssten? Kan betydelsen av samlandet och omflyttandet av sten i sig vara orsak till något sådant? Förutsättningen för detta är den ovan omtalade kontinuiteten i föreställningsvärlden, och den tycks finnas i perioden yngre bronsålder-äldre järnålder, möjligen ännu längre.

De stenklädda bergen har i huvudsak brukats under sen bronsålder och äldre järnålder. I ovan nämnda material finns dock en ringnål från vikingatid (Foss 239), en datering som sträcker sig in i vendeltid från Svarteborg 116, och dateringar som till och med sträcker sig in i medeltid (Svarteborg, 116). Dessa kan tyda på att bruket inte får något abrupt slut, utan att det finns kvar om än svagare in i yngre järnålder/äldsta medeltid. Betydelsen i och bruket av sten och stenpackningar, även stensättningar och röjningsrösen, kan alltså ha haft betydelse ända fram i medeltid, då det verkligt stora brottet i föreställningsvärlden sker. Övergången till den nya kulten, kristendomen, med hela dess kultur och världsbild förändrar situationen helt.

\section{Avslutning}

Kontinuitet eller återbruk, minne eller missförstånd, moderna eller historiska bör avgöras av huruvida brukande människor delar samma föreställningsvärld eller inte. Medeltidens och senare tids röjningar av åkermark resulterade i röjningsrösen, som ibland hamnade på eller ihop med äldre tiders röjningsrösen eller stensättningar. De senare har då sannolikt uppfattats som stenhögar eller äldre röjningsrösen. Vid järnålderns röjningsarbeten, däremot, kan man ha uppfattat gravarna annorlunda och haft ett annat förhållande till stenen (jfr Häggström, 2005).

Brukskontinuitet i fråga om kult är givetvis beroende av att grunden i föreställningsvärlden är ungefär densamma. Förändringar i denna ändrar också kultutövande, men en långsam reformering behöver inte betyda att man bryter med äldre seder och bruk. Förändringar kan enligt longue durée ske så långsamt att det inte märks och sederna följer sakta med. Större ändringar i samhället exempelvis socialt eller ekonomiskt eller genom olika typer av påverkan utifrån skapar nya behov som i sin tur bör skapa nya typer av kultutövning. Av förändringar följer att gamla seder och gamla platser glöms bort helt eller delvis. Vad det gäller betydelsen av sten, stenpackningar och omflyttning av sten ser jag ett långsamt föränderligt bruk, som börjar i början eller mitten av bronsålder och fortsätter åtminstone hela äldre järnålder, möjligen hela järnåldern.

En yta med både stensättningar och röjningsrösen kan som helhet vara betydelsebärande/kultiska ur skaparnas ögon om röjningsrösena skapats i en tid då också gravarna skapades och alltså i samma föreställningsvärld. Med tanke på att kultplatskontinuitet kan ha rått under lång tid skulle alla röjningsrösen fram till medeltid kunna räknas som ingående i samma tradition. De är då lika intressanta som gravarna och ett slags fortsättning på gravbyggandet. Däremot kan man inte tänka så om de röjningsrösen som är resultatet av 
uppodlingar i (kristen) medeltid och senare. Perioden vikingatid/tidig medeltid är svår att säga något säkert om. Något av den gamla föreställningsvärlden är möjligen kvar i yngre järnålder, men i (kristen) medeltid bör den vara helt borta. Medeltida röjningsrösen och även sentida sådana, som lagts på äldre röjningsrösen eller stensättningar, bör ha hamnat där på grund av att de äldre lämningarna uppfattats som tidigare upplagda röjningsrösen. Då är det likheten i utseenden, som är viktigt, inte underliggande föreställningar om kosmiska ting.

\section{Summary}

Articles in this book deal with the difficulty of differentiating between graves and clearance cairns. In this paper, I want to show that there are other types of ancient monuments that can be misinterpreted as either of these. The type of monument I present are stone-covered hillocks, cultic sites which show a long-term stability. This long-term usage is analyzed using the concept of longue durée.

A stone-covered hillock/mountainside is a much larger construction than graves or clearance cairns, and often contains graves and other structures, as well as flint, ceramics and other finds. They were built and used from the (middle) Bronze Age to the Migration period and possibly even during the Late Iron Age.

According to the concept of longue durée, change occurs steadily over long time, an example of which can be seen in the stone-covered hillock at the Tuve 46 site. This site was used from the middle of the Bronze Age to the Migration Period, and the nature of its use changed over the course of time: stones and blocks were gathered, the hillock was remodeled, there were fires, people were buried, graves, a cult house and mounds of fire-cracked stones were built, hearths, cooking-pits and small sacrificial spots were used and flint and ceramics were strewn or just left in the stone packing. Finally, at about AD 600, the site was abandoned. The change from a period of very heavy activity to something marked only by a few pieces of flint and ceramics, occurred around 500 BC. Throughout all this time, the stones, the stone packing and the transition of stones remained constant. This overall consistency relied upon the religious worldview of the time.

These graves and clearance cairns were built during the same period of time as the stone-covered hillocks and I presume that they all represent the same religious philosophy. It is possible that these stones, stone packings and transition of stones at the graves and clearance cairns carry the same meaning as those at the stone-covered hillock. If this is the case, then the mixture of graves and clearance cairns at the same place or succeeding each other in function is no coincidence, but an ongoing tradition.

Medieval and later clearance cairns, on the other hand, are different. The arrival of Christianity and Christian culture put a stop to the earlier concept of stones as bearers of meaning. When people in Christian times put clearance stones on graves or older clearance cairns, was due their similarity in appearance.

\section{Referenser}

Andersson, S. (1976). Tuve 65. Stensättning. Bronsålder/äldre järnålder. Fyndrapporter 1976. Rapporter över Göteborgs Arkeologiska Musei undersökningar, s. 85-144. Göteborg.

Artelius, T. (2008). Akropolis bortom världens ände. Variationer i människans återgivelser av den heliga verkligheten. I E. Hjärtner-Holdar, T. Ericsson \& A. Östling (Red.), Mellan himmel och jord. Ryssgärdet, en guldskimrande bronsåldersmiljö i centrala Uppland. Arkeologi E4 Uppland - studier. Volym 5, s. 481-496. Uppsala.

Artursson, M., Karlenby, L. \& Larsson, F. (Red.).(2011). Nibble. En bronsåldersmiljö i Uppland. Särskild undersökning 2007. E18 sträckan Sagån - Enköping. Uppland, Tillinge socken, Tillinge-Nibble 1:9 \& Tillinge-Mälby 5:1. Riksantikvarieämbetet. UV Rapport 2011, 111. Stockholm.

Bintliff, J. (1991). The contribution of an Annaliste/structural history approach to archaeology. I J. Bintliff (Red.), The Annales school and Archaeology, s. 1-33. London, New York.

Bradley, R. (1998). The Significance of Monuments. On the shaping of human experience in Neolithic and Bronze Age Europe. London, New York.

Braudel, F. (1980). On history. London.

Gerdin, A. -L. (1999). Rösen - Uttryck för makt eller platser där himmel och jord möts i det kosmiska rummet. I M. Olausson (Red.), Spiralens öga. Tjugo artiklar kring aktuell bronsåldersforskning, s. 47-74 Stockholm.

Häggström, L. (2005). Landskapsutnyttjande, bete och odling: på sydsvenska höglandet under järnålder, exemplet Öggestorp (diss), GOTARC. Series B. Gothenburg Archaeological Theses. No 34, Göteborgs universitet og Jönköpings läns museum.

Kaliff, A. (1997). Grav och kultplats. Eskatologiska föreställningar under yngre bronsålder och äldre järnålder $i$ Östergötland. Uppsala.

Karlenby, L. (2011). Stenbärarna. Kult och rituell praktik $i$ skandinavisk bronsålder. Uppsala.

Kraft, A. (2003). Röjningsrösen som transitionsmonument. En diskussion kring gravar i röjningsröseområden. I P. Lekberg (Red.), Texter kring ting och tid. Arkeologiska fenomen $i$ Kronobergs län, s. 93-114. Smålands museum. Växjö.

Kraft, A. (2013). Formspråk, färg och symbolik hos gravar. I A. Kraft \& G. Ängeby. Symbolik i gravar. Med arkeologiska undersökningar för E6 som grund, s. 7-68. Mölndal.

Lindqvist, M. \& Toreld, C. (2005). Gravar, skålgropssten och en neolitisk boplats vid Saltkällefjorden. Bohuslän, Munkedals kommun. Foss socken, Saltkällans säteri 1:2, RAÄ 239. Mellan fiord och fiäll. Boplatser från stenålder, gravar från brons- och järnålder. Teknisk rapport över de arkeologiska slutundersökningarna för E6 Småröd - Saltkällan, RA Ä 424, 425, 239 och 240. Foss socken i Munkedals kommun. Landskapet Bohuslän i Västra Götalands län. Bohusläns museum och Riksantikvarieämbetet UV Väst, s. 55-88. Uddevalla.

Lönn, M. (2009). En grav, en gravurna och en kvinna - Skee 1597. I M. Lönn \& G. Ängeby (Red.), Järnåldergravar i Skee. Delområde 2 inom sträckan E6, Lugnet-Skee. Bohuslän, Skee socken, Vättland 1:6 och Bastekärr 1:8. RAÄ Skee 1090 och 1597. s. 73-89. Mölndal.

Lönn, M. med bidrag av Apel, J. \& Brorsson, T. (2014). Kultplatsen på Stora Holm. Västra Götalands län, 
Västergötland, Göteborgs kommun, Tuve socken, Stora Holm 36:38, Tuve 46. Riksantikvarieämbetet, UV Rapport 2014:45, Arkeologisk undersökning.

Lönn, M. (2015). Kultberget på Stora Holm. In Situ, volym 11, 9-23.

Munkenberg, B. -A. (2003). Svarteborg 116 - En plats för ceremoniellt bruk? I P. Claesson, \& B. -A. Munkenberg (Red.), Projekt Gläborg - Rabbalshede. Arkeologiska undersökningar längs E6 i Bohuslän. Nr 1. Teknisk rapport, s. 131-157. Bohusläns museum. Uddevalla.

Munkenberg, B. -A. (2004). Monumentet i Svarteborg. I P. Claesson \& B. -A. Munkenberg (Red.), Projekt Gläborg Rabbalshede. Bygden innanför fjordarna. 3. Gravar och ritualer, s. 17-70. Bohusläns museum. Uddevalla.

Munkenberg, B. -A. (2012). Lämningar efter många företeelser och fenomen. In Situ 2011-2012, 39-63.

Munkenberg, B. -A. \& Claesson, P. (2014). Tanum 2213. I P. Claesson, m.fl. Arkeologi norr om Gerumsälven. Arkeologiska undersökningar för väg E6 $i$ Världsarv Tanum. Arkeologisk slutundersökning/teknisk rapport 1802, 2211, 2213 samt del av 2260 och 2261. Hoghem 1:1, Tanum socken, Tanums kommun. Bohusläns museum. Rapport 2014:40, s. 133-185. Uddevalla.

Vikstrand, P. (2001). Gudarnas platser. Förkristna sakrala ortnamn i mälarlandskapen. Uppsala.

Åberg, J. (2008). Söder om Bönekullen. Boplatser och gravfält vid Stora Holm. Arkeologisk förundersökning. Tuve 46, 63, 134, 167 samt Bpy 1, 2, 3, 4, 5, 6. Tuve 1:10 m fl, Tuve socken, Göteborgs kommun. Bohusläns museum. Rapport 2008:13. Uddevalla.

Ängeby, G. (2009). Gravfältet Skee 1090. I M. Lönn \& G. Ängeby, Järnåldersgravar i Skee. Delområde 2 inom sträckan E6, Lugnet - Skee. Bohuslän, Skee socken, Vättland 1:6 och Bastekärr 1:8, RÄ̈ 1090 och 1597. UV Väst rapport 2009:2, s. 11-72. Arkeologiska undersökningar. Riksantikvarieämbetet, Avdelningen för arkeologiska undersökningar, Mölndal.

Ängeby, G. \& Connelid, P. (2016) med bidrag av Stilborg, O., Heimdahl, J. Arcini, C. \& Strucke, U. Gravar och fossil åkermark. Riksväg 40, Dållebo-Hester, del 1. Rapport 2016:95. Arkeologiska och agrarhistoriska undersökningar Västra Götalands län, Västergötland, Ulricehamns kommun, Södra Vings socken, Intakan 1:7, Romsås 5:5, Getared 2:1, Övre Nordkvarnen 1:6, Vings Sjögården 1:8, Vings Torp 1:3, Ekeslunda 2:2, Södra Ving 79:1, 240:1, 294:1-2, 277:1, 295:1. Arkeologerna. Statens historiska museer. Stockholm.

Östlund, A. \& Swedberg, S. (2014). Del 4b. Kompletterande särskild undersökning av Tanum 1796 och särskild undersökning av Tanum 2259 etapp II. I A. Östlund \& S. Swedberg (Red.), Arkeologi söder om Gerumsälven. Särskild undersökning av Tanum 1796, 1821, 1910 och 2259 samt kompletterande särskild undersökning av Tanum 1796, s. 107-144. Kulturlandskapet rapporter 2014:6. Kulturlandskapet. Fjällbacka. 